\title{
Reconstruction of drought episodes for central Spain from rogation ceremonies recorded at the Toledo Cathedral from 1506 to 1900: A methodological approach
}

\author{
Fernando Domínguez-Castro ${ }^{\text {a, }}$, Juan I. Santisteban ${ }^{\text {b }}$, Mariano Barriendos ${ }^{\mathrm{c}}$, Rosa Mediavilla ${ }^{\mathrm{a}}$ \\ a Dirección de Geología y Geofisica, Instituto Geológico y Minero de España, C/La Calera 1, 28760-Tres Cantos (Madrid), Spain \\ ${ }^{b}$ Department of Stratigraphy, Fac. Geological Sciences, University Complutense of Madrid, José Antonio Novais 2, 28040-Madrid, Spain \\ ' Department of Modern History, University of Barcelona, Montalegre 6, 08001-Barcelona, Spain
}

\section{Keywords:}

rogation ceremonies

Mediterranean climate extremes

drought

central Spain

SPI

\begin{abstract}
A B S T R A C T
Rogation (ceremonies to ask God for rain: pro-pluvia, or to stop raining: pro-serenitate) analysis is an effective method to derive information about climate extremes from documentary data. Weighted annual sum by levels has been a widespread technique to analyze such data but this analysis is liable to be biased to spring values as these ceremonies are strongly related to farming activities. The analysis of the length of propluvia periods (the time span during which rogations are carried out in relation to a drought event) and the combination of annual and seasonal information offers a more objective criterion for the analysis of the drought periods and an increase in the resolution of the study.

Analysis by the pro-pluvia periods method of the rogation series from the Toledo (central Spain) Cathedral Chapter allows a good characterization of the droughts during the 1506-1900 period. Two drought maxima appear during the 1600-1675 and 1711-1775 periods, characterized by rogations during almost all the year, with a middle stage (1676-1710) when droughts were less frequent and their length shortened.

Sea level pressure patterns for the instrumental and documentary periods show that droughts were mostly related to a north-eastern position of the Azores High that displaced the Atlantic low pressure systems towards a northern position. There is a weak relation with the North Atlantic Oscillation but this fact is related to the local character of the series that increases the weight of the local factors.

Comparison of rainfall/drought records around Spain and the Western Mediterranean reveals the heterogeneity of their distribution in time and space as well as stresses the need of more and longer reconstructions. Better knowledge of drought variability would help to improve regional models of climate extremes and the understanding of the atmospheric pattems related to their development.
\end{abstract}

\section{Introduction}

Drought is one of the climate extremes with greatest incidence in human development. Water is needed for human life for drinking and to obtain food, as natural or artificial irrigation is needed for agriculture and also for the cattle. Relevance of drought in human activity is testified by migratory movements from dry regions to wetter areas and by decline of civilizations and empires as consequence of prolonged water deficit (Weiss et al., 1993; Cullen et al., 2000; deMenocal, 2001; Hodell et al., 2001, 2007; Hauget al., 2003; Nicoll, 2004; Drysdale et al., 2006). But it is also important as an increase in climate extremes is very likely in the Mediterranean region in future scenarios (Brunetti et al., 2004; Tebaldi et al., 2006).

\footnotetext{
* Corresponding author. Tel.: +3491 7287288; fax: +34917287272.

E-mail addresses: f.dominguez@igme.es (F. Domínguez-Castro), juancho@geo.ucm.es (J.I. Santisteban), mbarriendos@ub.edu (M. Barriendos), r.mediavilla@igme.es (R. Mediavilla).
}

One of the difficulties in the research of drought is its definition (meteorological, hydrological, agricultural, socioeconomical droughts, Wilhite and Glantz, 1985), which determines its metrics and the threshold of rainfall deficit (duration of the deficit) that defines the "drought state". Depending on the key parameter chosen to define the drought event there are several indexes that can be used to quantify drought: i.e. Palmer Drought Standardized Index (PDSI, Palmer, 1965), Standardized Precipitation Index (SPI, McKee et al., 1993), “Percent of Normal”, deciles (Gibbs and Maher, 1967), etc. These indexes are of variable complexity and, usually, they provide non-comparable results (Byun and Wilhite, 1999) or use assumptions weakly justified on a physical or statistical model (Alley, 1984).

But most studies of recent droughts coincide in the great variability in time and space of drought (Santos et al., 2000). This fact determines that rainfall threshold is dependent on the location of the study (Hisdal and Tallaksen, 2000).

Droughts have been mostly studied for short time scales (ranging from 50 to $150 y r$ ) based on instrumental data and they stress the need of longer time series in order to improve knowledge on the retum periods 
of drought events and the changes in its spatial dis ribution(Santos et al., 2000).

Long drought/rainfall data sets arising from dendrochronology for the Mediterranean basin are mainly limited for a few regions: Morocco (Munaut, 1982, Till and Guiot, 1990; Chbouki et al., 1995; Glueck and Stockton, 2001; Esper et al., 2007), Turkey (Akkemik, 2000; D’Arrigo and Cullen, 2001; Touchan et al., 2003, 2005a; Akkemik and Aras, 2005; Akkemik et al., 2005; Akkemik et al., 2007), Spain (Creus et al., 1995, 1997; Saz and Creus, 1999, 2001; Saz, 2004) and East Mediterranean - Greece, Turkey, Lebanon, Syria and Cyprus (Touchan et al., 2005b). But the great variations in precipitation from one place to another makes difficult to find a homogeneous response of ring-width to precipitation, and because the long-lived trees, useful for this research, grow in areas where precipitation is not a limiting factor (Martinelli, 2004).

To extend the spatial coverage of these series one of the more valuable proxies are documentary data as they provide descriptions of weather and their time resolution can reach up to daily scale.
During recent decades, historical climatology has been increasingly contributing to analyze the climate variability of the last millennium (Brázdil et al., 2005; Luterbacher et al., 2006). One of the methods contributing to such advance has been the analysis of rogation ceremonies to estimate rainfall or drought series.

These ceremonies are a typical ritual of the Roman Catholic Church that was used in all the Spanish Empire to sight for the end of the Divine punishment of drought periods (pro-pluvia rogations) or long wet/stormy spells (pro-serenitate rogations).

Their potential as a climate proxy was recognized by Giralt (1958) and due to their wide time range and their systematic record in the archives of a considerable number of localities of the "Catholic world" (Barriendos, 2005) they have been frequently used (Âlvarez Vázquez, 1986; Martín-Vide and Barriendos, 1995; Barriendos, 1997, 2005; Piervitali and Colacino, 2001; Romero and Máyer, 2002; Zamora Pastor, 2002; Vicente-Serrano and Cuadrat, 2007; Rodrigo and Barriendos, this volume).

Methods to quantify these data vary from the simple counting of the number of ceremonies by year or trying to find the relation between the

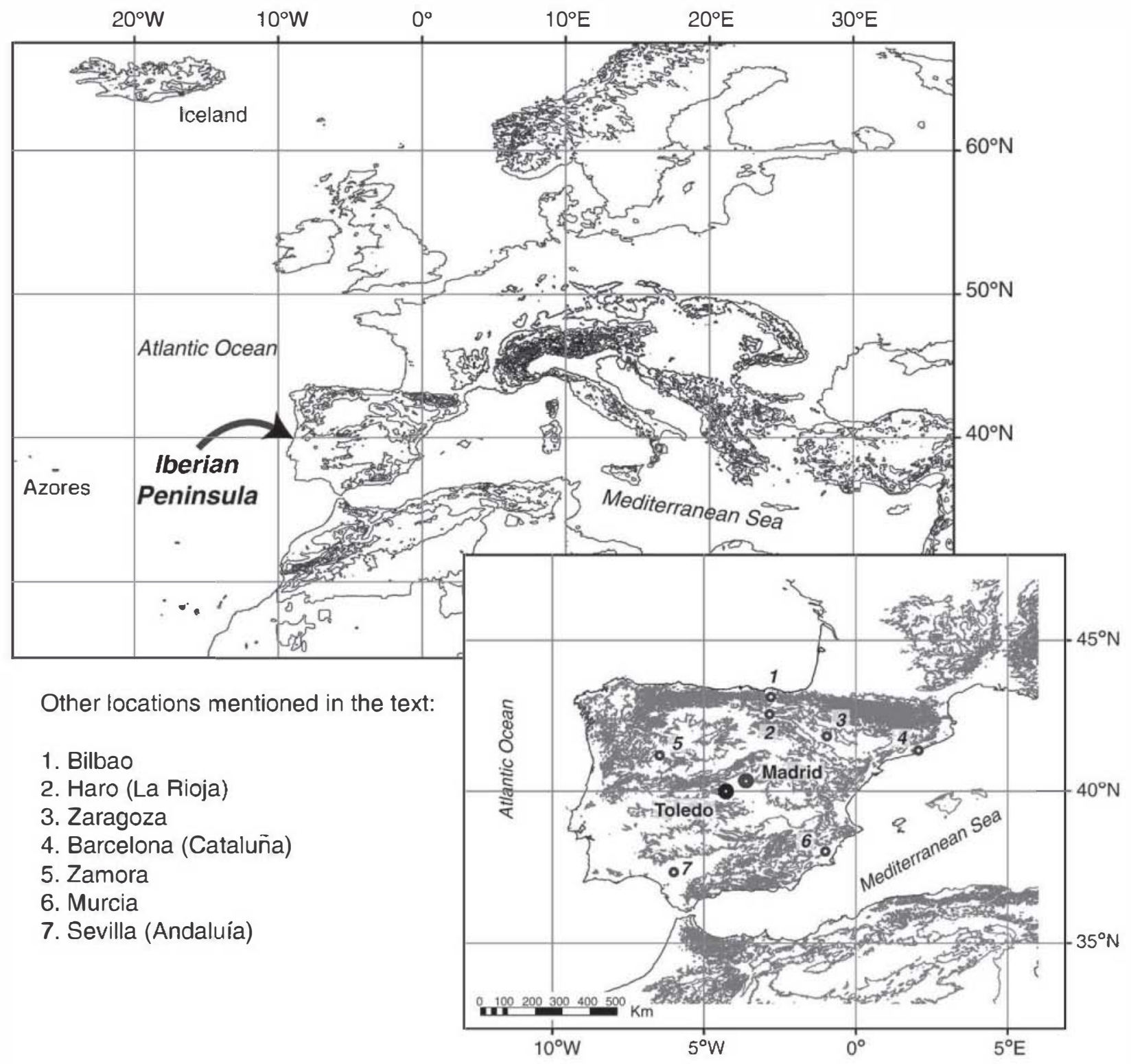

Fig. 1. Location of the studied area. 
economical cost of these ceremonies and the droughts (Álvarez Vázquez, 1986) to weighted sums of the ceremonies on an annual or longer time scale with discrete weights related to the liturgical acts developed in each situation (Martín-Vide and Barriendos, 1995; Barriendos, 1997. 2005; Piervitali and Colacino, 2001; Romero and Máyer, 2002; Zamora Pastor, 2002). Filtering of the results by running averages ranging from 5 yr to 31 yr (Martín-Vide and Barriendos, 1995; Barriendos, 1997, 2005; Zamora Pastor, 2002; Vicente-Serrano and Cuadrat, 2007) is a usual technique to mask the high frequency signals and to reveal the long-term trends.

This paper focuses on the analysis of rogations by using the duration of periods defined by a set of ceremonies close in time instead of using the usual weighted sum of ceremonies in order to obtain an estimate of the length of the drought periods. The application of this methodology to the rogation series from the Toledo Cathedral (central Spain) will serve to characterize the 1506-1900 AD period in inland Spain.

\section{Location}

Toledo is located in the Southern Spanish Meseta $\left(39^{\circ} 51^{\prime} \mathrm{N}, 4^{\circ} 01^{\prime} \mathrm{W}\right)$ at $540 \mathrm{~m}$ above sea level (Fig. 1). It is protected from the marine influence by the Central System and Sierra Morena. From the 6th century $A D$ until $1563 \mathrm{AD}$ it was the Spanish capital, but it's still an important administrative and religious centre (archiepiscopate).

Present day climate is temperate Mediterranean-continental with $357 \mathrm{~mm}$ of average annual rainfall, a dry period in summer, cold winters (average: $7.3^{\circ} \mathrm{C}$ ), warm summers (average: $24.6{ }^{\circ} \mathrm{C}$ ) and a wide annual range of temperature (from $-10^{\circ} \mathrm{C}$ in winter to up to $40{ }^{\circ} \mathrm{C}$ in summer).

\section{Source of data and methods}

\subsection{Data}

Rogation data come from the 1) Toledo Cathedral Chapter Acts, 121 volumes that record the daily life from 1466 to 1599 AD, 2) "Casos subcedidos en diversos tiempos en la Sta. Iglesia de Toledo desde el año 1435 sacados de los libros capitulares de ella" a book started by Juan Bautista de Chaves Arcayos who resumed the cathedral chapter records from 1434 to $1599 \mathrm{AD}$ and incorporated his own news and was later followed by other chapter members until the middle 18th century AD, 3) Chapter Books (1464-1914), 331 volumes used to fill gaps in the Chapter Acts. Those books were studied at the Toledo Cathedral Archives and at the Toledo Townhall Archives.

The collected rogation series covers from 1506 to 1900 and it is composed by 341 pro-pluvia rogations, 36 pro-serenitate rogations and 94 thanksgiving masses (ceremony to celebrate the end of the weather phenomena that led to a rogation). Most of these rogations correspond to spring ceremonies (Fig. 2a) and distribution of levels in time is not homogeneous (i.e. Level III ceremonies are more frequent during the 16th century, Fig. 2b).

As Rodrigo and Barriendos (this volume) point, there is no overlapping period with the instrumental series of Toledo (covering the 1909-2002 period). But comparison of Toledo series (Buenavista and Lorenzana stations) to the instrumental record of Madrid (Retiro station) reveals a good correlation of their rainfall series both in number of rainy days (Fig. 3a), amount of rainfall (Dominguez-Castro, 2004) and the derived Standard Precipitation Index (Fig. 3b). As a consequence, Madrid rainfall series were chosen as reference series in this paper.

The annual correlation coefficient for the days of rain of the two stations is the 0.894 and Fig. 3a shows the similarity on the distribution of the days of rain per month at Toledo and Madrid. Table 1 shows that Madrid is slightly rainier than Toledo, but the correlation coefficient for both cities is high for all seasons and the Coincidence Index (Dominguez-Castro, 2004) supports the similarity of both series

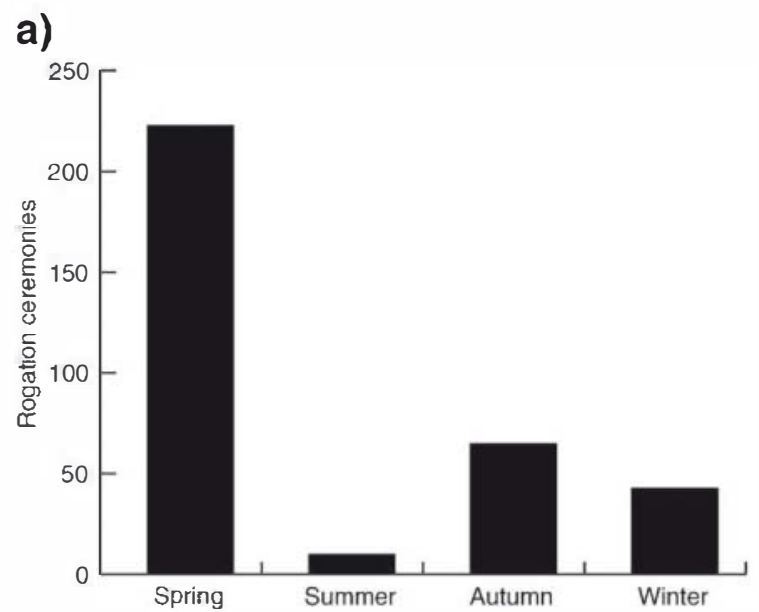

b)

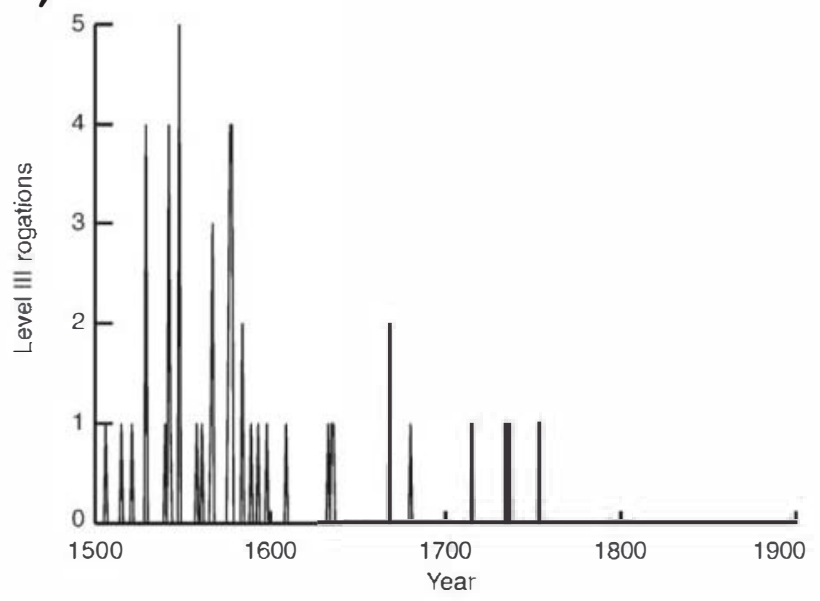

Fig. 2. a) Seasonal distribution of pro-pluvia rogations (1506-1900) and b) distribution of Level III rogations in Toledo series.

(Table 1). This index (CI) gives an idea of the similarity of the series at daily scale and it is calculated as:

$\mathrm{CI}=(\mathrm{CD}-\mathrm{DMC}) /(\mathrm{TD}-\mathrm{DMC})$

where $\mathrm{CD}$ (coincidence of days) is the number of rainy or dry days that coincide in both cities, TD (total days) is the length of the studied time window, in our case one season, and DMC (days of mandatory coincidence) is the number of rainy or dry days that mathematically must coincide (i.e., if Madrid series is composed by 60 days of rain and 40 dry days and Toledo series shows 30 rainy days and 70 dry days, there are 10 dry days that must coincide, then $\mathrm{DMC}=10$ ).

Madrid series has been constructed with the data provided by the Meteorological National Institute of Spain filling some gaps with the GHCN series (Peterson and Vose, 1997) covering the 1850-2002 period and imputing missing values with the Enhanced-Maximisation (EM) and Data-Augmentation (DA) algorithms (Schafer, 1997). Further extension of the series has been achieved by means of a generalized lineal model of the number of rainy days by month (obtained from daily reports of the Royal Academy of Medicine) to the monthly rainfall extending the series down to 1786 (with some gaps).

The Standardized Precipitation Index (SPI), both for Toledo and Madrid, has been elaborated following Lloyd-Hughes and Saunders (2002) but using the Pearson III distribution as proposed by VicenteSerrano (2006). This index was selected by its properties: only depends on rainfall data, provides information on duration, magnitude and intensity of droughts (Hayes et al., 1999) and it can be calculated for several time scales allowing to identify various types of 
a)
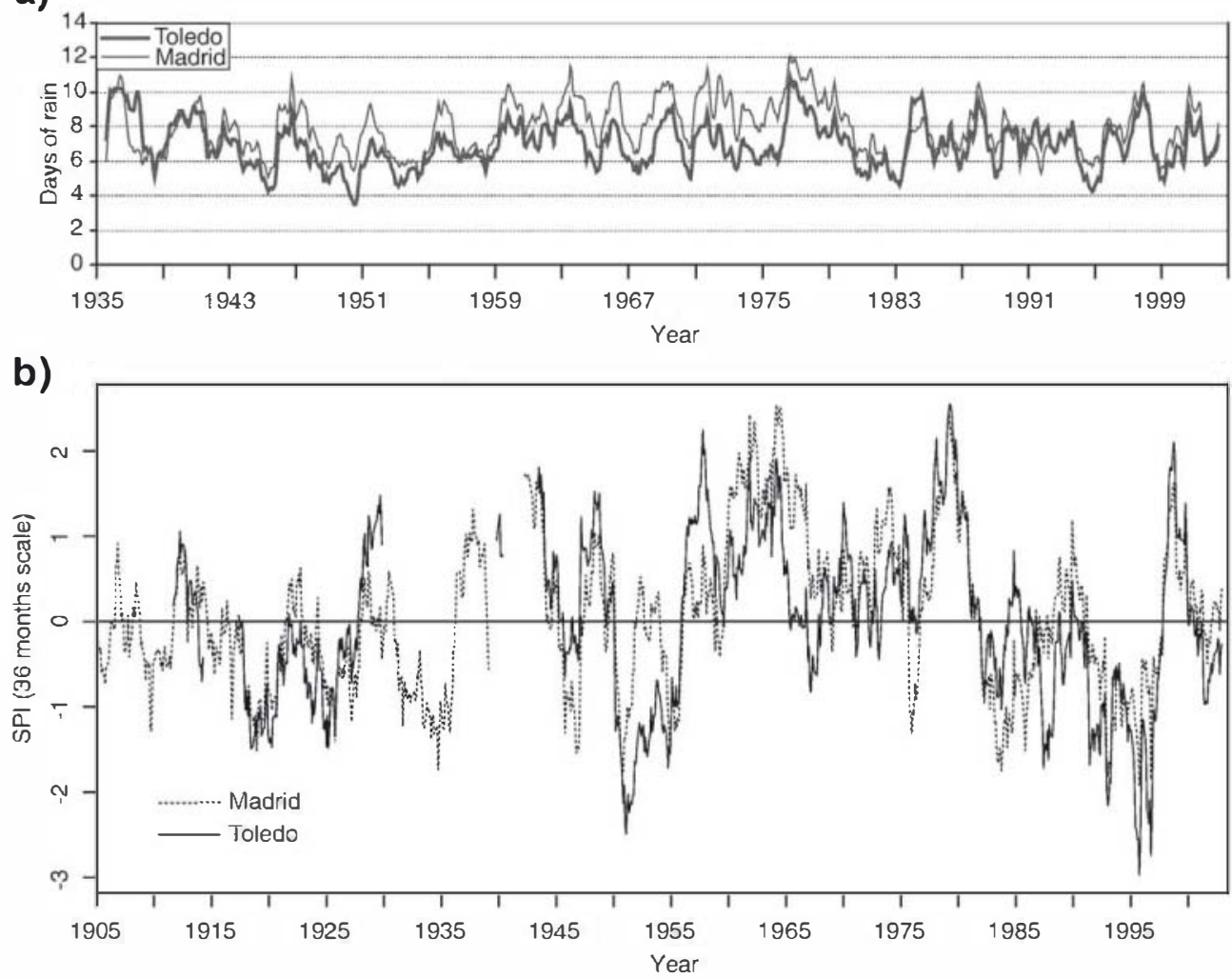

Fig. 3. a) 12-month running average of rainy days by month for Madrid (thin line) and Toledo (thickline) for the 1935-2002 period. b) SPI at 36 months scalef or Madrid and Toledo from 1905 to 2002

drought (agricultural, meteorological, hydrological or environmental) (Vicente-Serrano, 2006).

\subsection{Methodology}

In order to characterize the drought periods, this paper just focuses in the pro-pluvia rogations.

Our main methodological goal is to develop an estimate of drought duration based on the length of the periods between ceremonies, as an alternative to the use of the levels of the ceremonies as discrete weights.

\subsubsection{Estimates of drought length}

Common weighting of rogations is based on a hierarchy of liturgical rituals that rose in importance as the severity of the drought increased. But that rank of ceremonies changed among localities both in number and manifestations giving place to different scales (Table 2).

Changes with time in the preferences of the city council or religious authorities can also mask the real severity of a drought. As an example, Level III processions are concentrated during the 16th century (Fig. 2b), but the "abundant" grain production during this century, in comparison to the 17th century production (Fig. 4), points to a not so unfavourable climate conditions.

In consequence, weighting of rogation by levels provides an inhomogeneous measure of drought, as its meaning varies in time and space, difficult to apply for the comparison among periods and localities.

But, independently of their level, these ceremonies use to be grouped in time defining a "pro-pluvia period" (PP) that spans from the date of a first ceremony that can be followed by successive rogations separated in time less than 20 days (a time threshold between periods), to the date of an ending thanksgiving mass or rogation. A special but not so infrequent case is a PP defined by a single rogation ceremony. The PP can overlap with the rainy period following the drought and, therefore, it doesn't provide a precise date of the end of the dry conditions but of the water deficit, which is the criteria for drought definition. So, the PP represents the amount of time that a community was continuously praying for the end of drought, what means an amount of rain enough to alleviate the water deficit.

Therefore, total length of the drought period is equal to the sum of the lengths of the PP and the previous dry period (PDP) that predates

Table 1

Seasonal average of rainy days (1935-2002) for Madrid and Toledo

\begin{tabular}{|c|c|c|c|c|c|c|c|c|}
\hline & \multicolumn{3}{|l|}{ Madrid } & \multicolumn{3}{|l|}{ Toledo } & \multirow[b]{2}{*}{$\begin{array}{l}\text { Correlation } \\
\text { coefficient* }\end{array}$} & \multirow[b]{2}{*}{$\begin{array}{l}\text { Coincidence } \\
\text { Index }\end{array}$} \\
\hline & Rainy days & $\begin{array}{l}\text { Precipitation } \\
(\mathrm{mm})\end{array}$ & $\begin{array}{l}\text { Standard deviation } \\
(\mathrm{mm})\end{array}$ & Rainy days & $\begin{array}{l}\text { Precipitation } \\
(\mathrm{mm})\end{array}$ & $\begin{array}{l}\text { Standard deviation } \\
(\mathrm{mm})\end{array}$ & & \\
\hline Winter & 33.94 & 133.3 & 71.0 & 29.95 & 106.9 & 58.0 & 0.90 & 0.76 \\
\hline Spring & 34.50 & 131.0 & 52.3 & 30.86 & 115.5 & 52.5 & 0.81 & 0.75 \\
\hline Summer & 17.53 & 50.4 & 29.3 & 14.42 & 46.2 & 30.3 & 0.82 & 0.64 \\
\hline Autumn & 26.08 & 137.8 & 72.3 & 22.33 & 105.1 & 48.0 & 0.82 & 0.73 \\
\hline
\end{tabular}

$*: p<0.01$. 
Table 2

Drought severity levels accordingly to the liturgical rituals of different cities

\begin{tabular}{|c|c|c|c|c|c|c|}
\hline & \multicolumn{4}{|c|}{ Barriendos (1997, work in progress) } & \multirow{2}{*}{$\begin{array}{l}\text { Romero and Máyer } \\
(2002) \\
\text { Gran Canaria }\end{array}$} & \multirow{2}{*}{$\begin{array}{l}\text { Zamora Pastor, } \\
(2002) \\
\text { Orihuela }\end{array}$} \\
\hline & Sevilla & Murcia & Toledo & Barcelona & & \\
\hline Level I & $\begin{array}{l}\text { Collecta pro pluvia and } \\
\text { intra ecclesiam prayers } \\
\text { with exhibition of the } \\
\text { Blessed Sacrament. }\end{array}$ & $\begin{array}{l}\text { Joy Masses, Collecta pro } \\
\text { pluvia. }\end{array}$ & $\begin{array}{l}\text { Masses with Collecta pro } \\
\text { pluvia and chants. }\end{array}$ & $\begin{array}{l}\text { Simple rogations, novenarios } \\
\text { and Collecta pro pluvia. }\end{array}$ & $\begin{array}{l}\text { "Water Mass", penitences } \\
\text { and prayers. }\end{array}$ & Public rogations \\
\hline Ievel II & $\begin{array}{l}\text { Intra ecclesiam liturgical } \\
\text { acts with images. }\end{array}$ & $\begin{array}{l}\text { Exhibition in the Cathedral of } \\
\text { Madonnas or Lignum Crucis. }\end{array}$ & $\begin{array}{l}\text { Novenarios with exhibition } \\
\text { of images and procession } \\
\text { inside the Cathedral. }\end{array}$ & $\begin{array}{l}\text { Exhibition of relics in the } \\
\text { Cathedral Main Altar. }\end{array}$ & $\begin{array}{l}\text { Processions with the city } \\
\text { saints. }\end{array}$ & $\begin{array}{l}\text { Masses with } \\
\text { Collecta pro } \\
\text { pluvia. }\end{array}$ \\
\hline Ievel III & $\begin{array}{l}\text { Extra ecclesiam liturgical } \\
\text { acts with images. }\end{array}$ & $\begin{array}{l}\text { Processions to sanctuaries } \\
\text { with images or relics. }\end{array}$ & $\begin{array}{l}\text { Processions with images } \\
\text { or relics inside the city. }\end{array}$ & $\begin{array}{l}\text { Procession along the main } \\
\text { streets with relics. }\end{array}$ & $\begin{array}{l}\text { General processions with } \\
\text { the city and town saints } \\
\text { and the Island patron. }\end{array}$ & $\begin{array}{l}\text { Exhibition of } \\
\text { the intercessor }\end{array}$ \\
\hline Level IV & $\begin{array}{l}\text { Procession around the city } \\
\text { with the image of the } \\
\text { Holy Christ. }\end{array}$ & General blessing of the fields. & $\begin{array}{l}\text { Processions with images } \\
\text { or relics around the city } \\
\text { reaching the city walls. }\end{array}$ & $\begin{array}{l}\text { Immersion in the harbour of the } \\
\text { Lignum Crucis. Exhibition of the } \\
\text { Blessed Sacrament, masses. } \\
\text { General blessing of fields. }\end{array}$ & & $\begin{array}{l}\text { Procession of } \\
\text { the intercessor. }\end{array}$ \\
\hline Ievel V & $\begin{array}{l}\text { Processions to sanctuaries } \\
\text { with relics, Lignum Crucis } \\
\text { or inside the Cathedral } \\
\text { with images. }\end{array}$ & & & Pilgrimages. & & \\
\hline
\end{tabular}

the PP. Pro-pluvia period length can be calculated from the dates of the rogations but, without any other information, it is impossible to know the length of the previous dry period.

Fig. 5a shows the drought length (DL) and the PDP and PP values for years with both daily instrumental (number of rainy days or amount of rain) and rogation records for the 1817-1900 period. One of the most relevant facts is that the PDP (the dry period which riggers the rogation mechanism) oscillates around 44.2 days with a standard deviation of 7.7 days and no data goes beyond $\pm 2 \sigma$. Such low variability implies that it is possible to obtain a statistically meaningful estimate of DL from the PP values without knowledge of the PDP (Fig. Sb). It is worth to note the similarity between the intercept of the lineal model (45.55) and the mean of the PDP, what means that this term is captured by the model.

Further support for this relation is provided by the comparison of the length of the pro-pluvia period by season to the seasonal SPI for the 1850-1900 period (in order to use direct measurements of amount of rainfall) that allows to establish a lineal relation between the magnitude of both indexes $(r=-0.44, p<0.01)$. The correlation of both indexes is lower than in the case of the relation between DL and PP. This can be attributed to the fact that rogations are triggered by a rainfall deficit below a certain threshold, but once surpassed that threshold the rogation phenomena is mostly controlled by the DL and it shows low sensitivity to the variations in the amount of rain while the SPI is sensitive both to the DL and to the amount of rainfall. Coincidence in time of rogations with negative SPI values (dry periods) is presented in Fig. 5d. This figure is also important as it makes clear that while rogations are coincident with drought events, not all drought events are accompanied by a rogation. Thus, rogations are evidence of drought events but they are not a continuous record of drought and this must be taken into account when using these ceremonies to reconstruct drought records.

These results, besides the fact that the number of rogations is lower than the average due to political factors during the last half of the 19th century, suggest that the length of the pro-pluvia period can be used as a proxy of the total length of the drought with a not so large uncertainty.

Single rogations, those located beyond 20 days of other rogation or thanksgiving mass, have no pro-pluvia period length by themselves and they have been assigned a length of 1 day.

\subsubsection{Seasonal vs. annual scale}

Several researchers have highlighted the benefit of the seasonal vs. annual resolution in historical climate analysis (Le Roy Ladurie, 1983; Xoplaki et al., 2001, 2005; Luterbacher et al., 2004, 2006; Brázdil et al., 2005; Frank and Esper, 2005; Casty et al., 2005; Pauling et al., 2006; Büntgen et al., 2006; Raible et al., 2006). This is evident in the Mediterranean region, characterized by the contrast among seasons. But in the case of the analysis of rogations, this fact is emphasized by the strong link between rogations and farming activities, which concentrate their water demand in certain periods of the year. This is demonstrated by the documents concerning the rogations: “... being so necessary water, both for the fields, as it is impossible neither to sow nor to sustain the animals, and for the health..." (Toledo

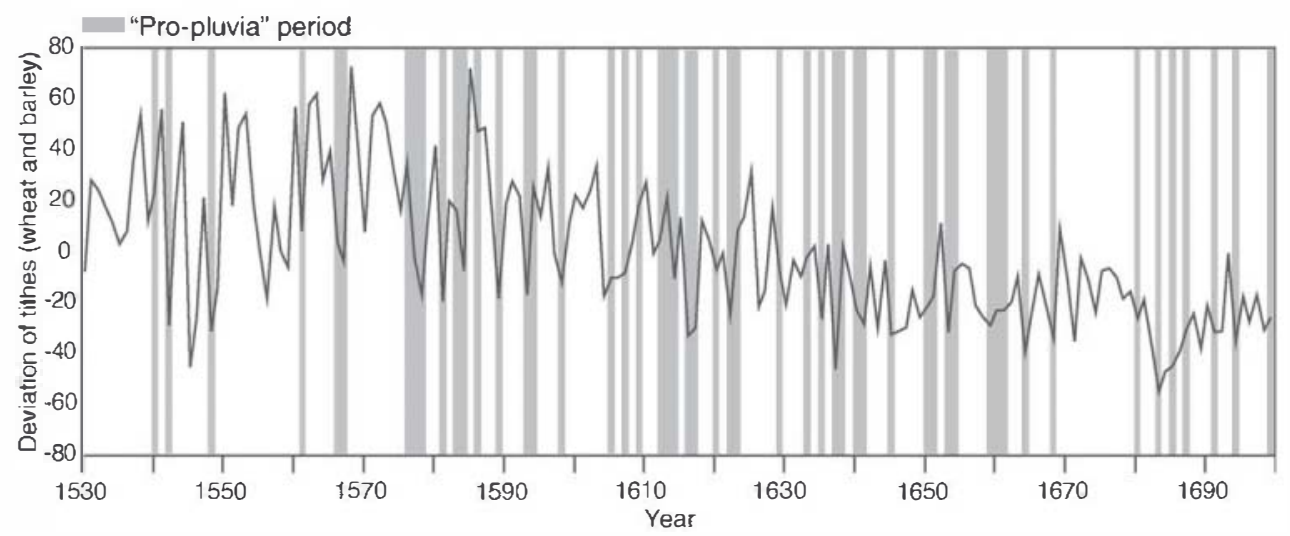

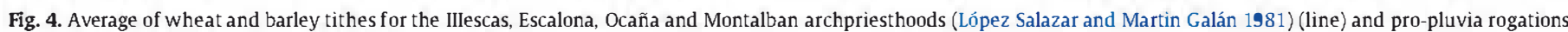
(bars) distribution for the $1530-1699$ period. 
a)

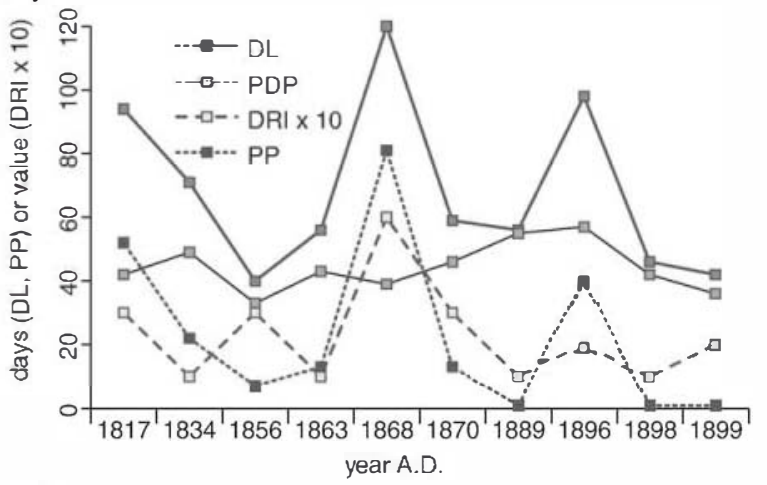

c)

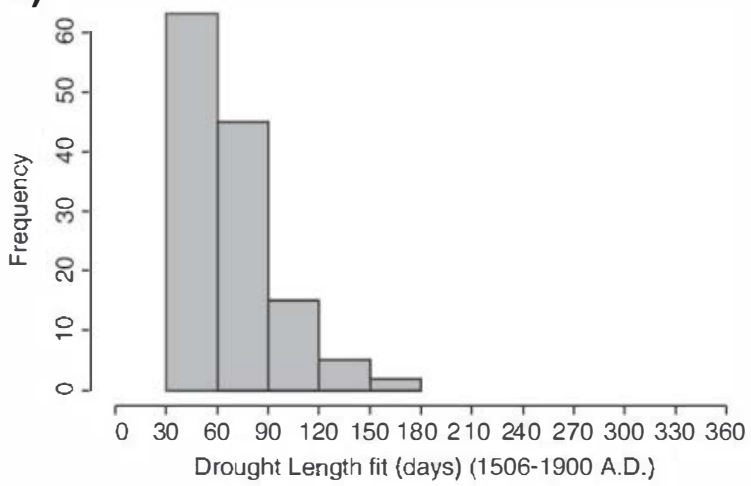

b)

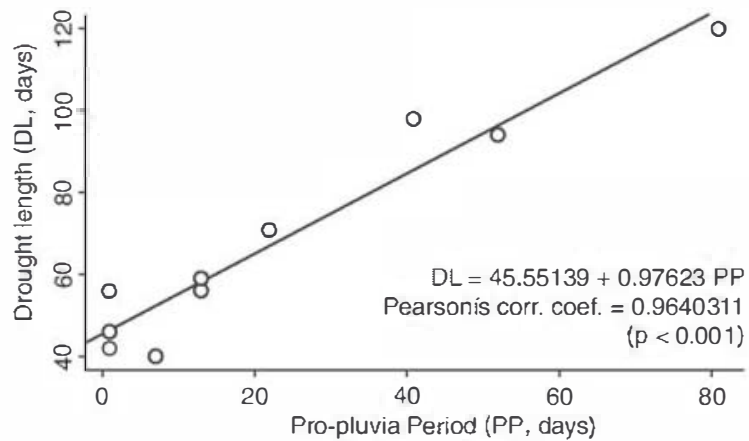

d)

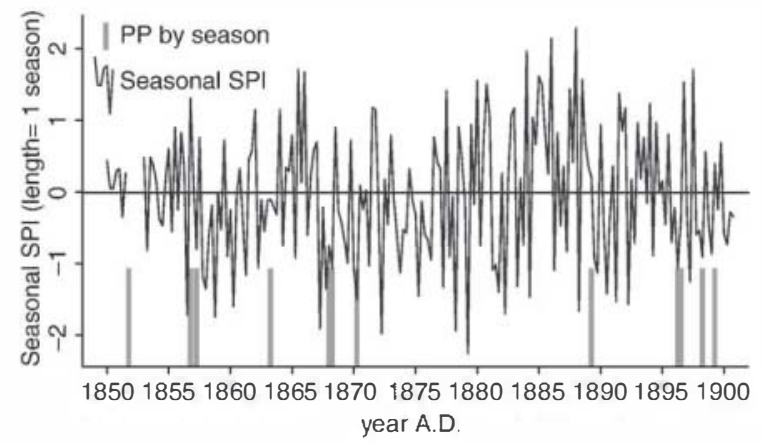

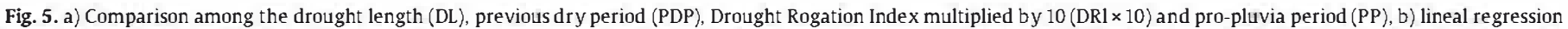

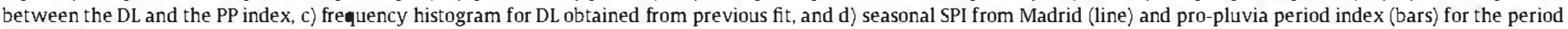
$1850-1900$.

Cathedral Chapter Acts, vol. 56, sheet 21, rogation on 15th of November of 1726). Fig. 4 presents the relation between wheat and barley tithes (López Salazar and Martin Galán, 1981), a grain production proxy, and rogations. Despite the possible influence of social, economical or technological factors in some of the events or trends, the near constant coincidence between years of scarce grain production and rogations supports the relation between farming activity and rogations.
The seasonality on water demand from farming activities conditions the interpretation and quantification of drought periods as the threshold to trigger a rogation was not the same in spring (growth of crops) or autumn (preparation of sowing, growth of pastures) as in summer (which was assumed to be dry and a rogation will be triggered by an exceptional drought). Consequently, rogations are shifted towards those seasons (Fig. 2a) causing a bias of the annual estimations.

\section{a)}

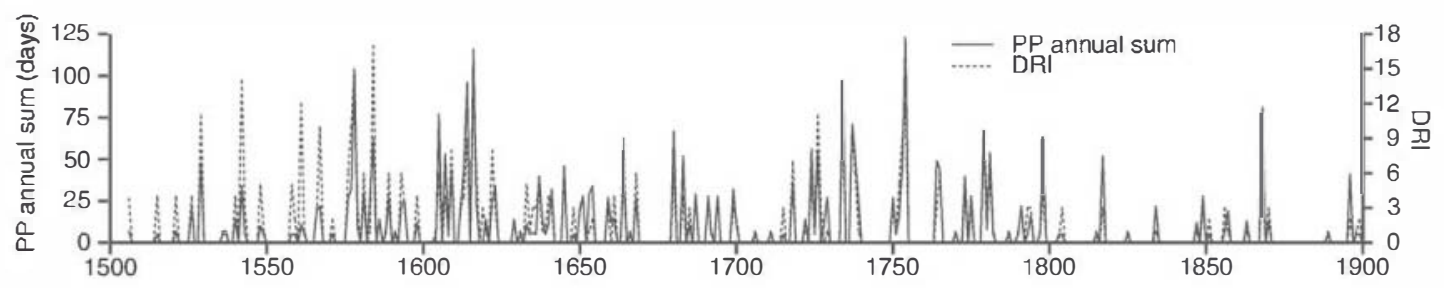

b)

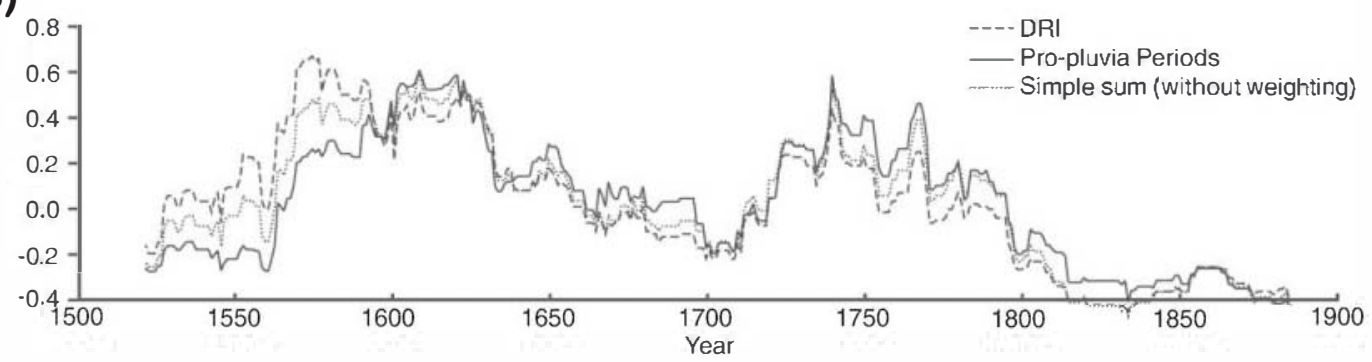

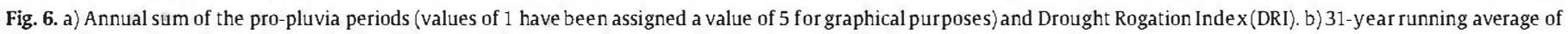
the standardized DRI (dashed), standardized PP method (continuous) and standardized non-weighted sum of rogations (dotted). 
The distribution of the drought length obtained by fitting the lineal model of Fig. 5b for the 1506-1900 A.D. period shows that most rogations represent events shorter than a season and no rogation represents droughts that exceed two seasons (Fig. 5c). Consequently, single rogations provide information about annual and seasonal droughts but not about longer periods. This is also evidenced in Fig. 5d as rogations coincide with dry periods marked by the SPI but their distribution in is not denser in these periods.
3.3. Comparison between the pro-pluvia period method and the Drought Rogation Index

In order to check the gain obtained with the pro-pluvia period method, we have compared the results of this method with those obtained by the use of the Drought Rogation Index (DRI, Martin-Vide and Barriendos, 1995) for the years with both available rogations and historical-instrumental data (Fig. 5a).

\section{a) Daily resolution}

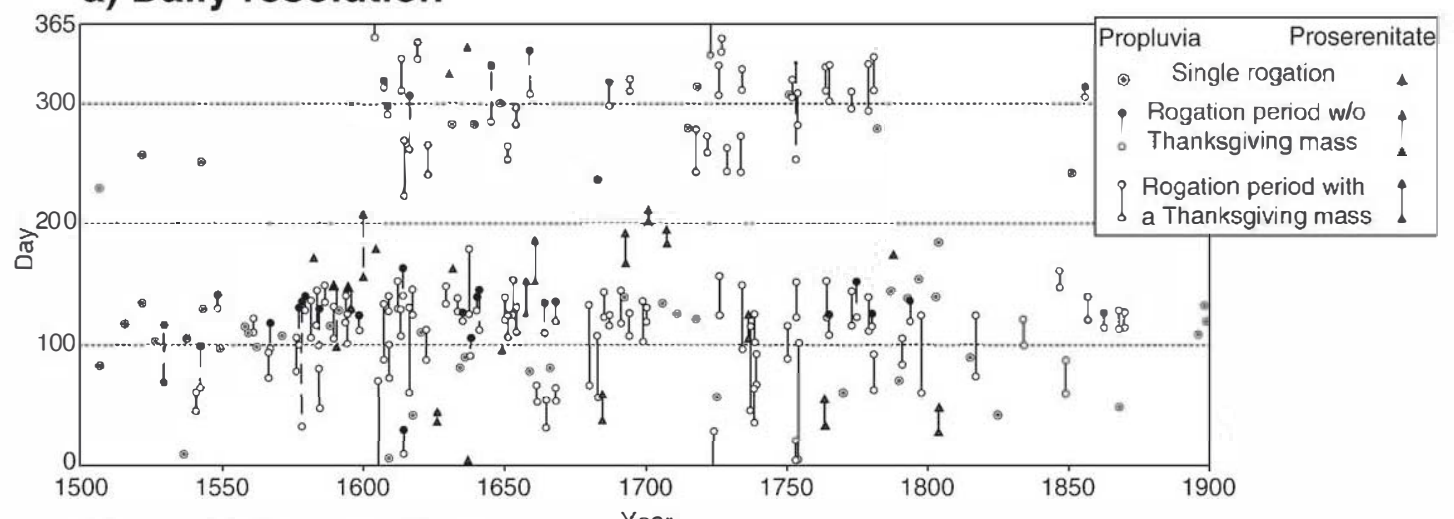

b) Annual resolution
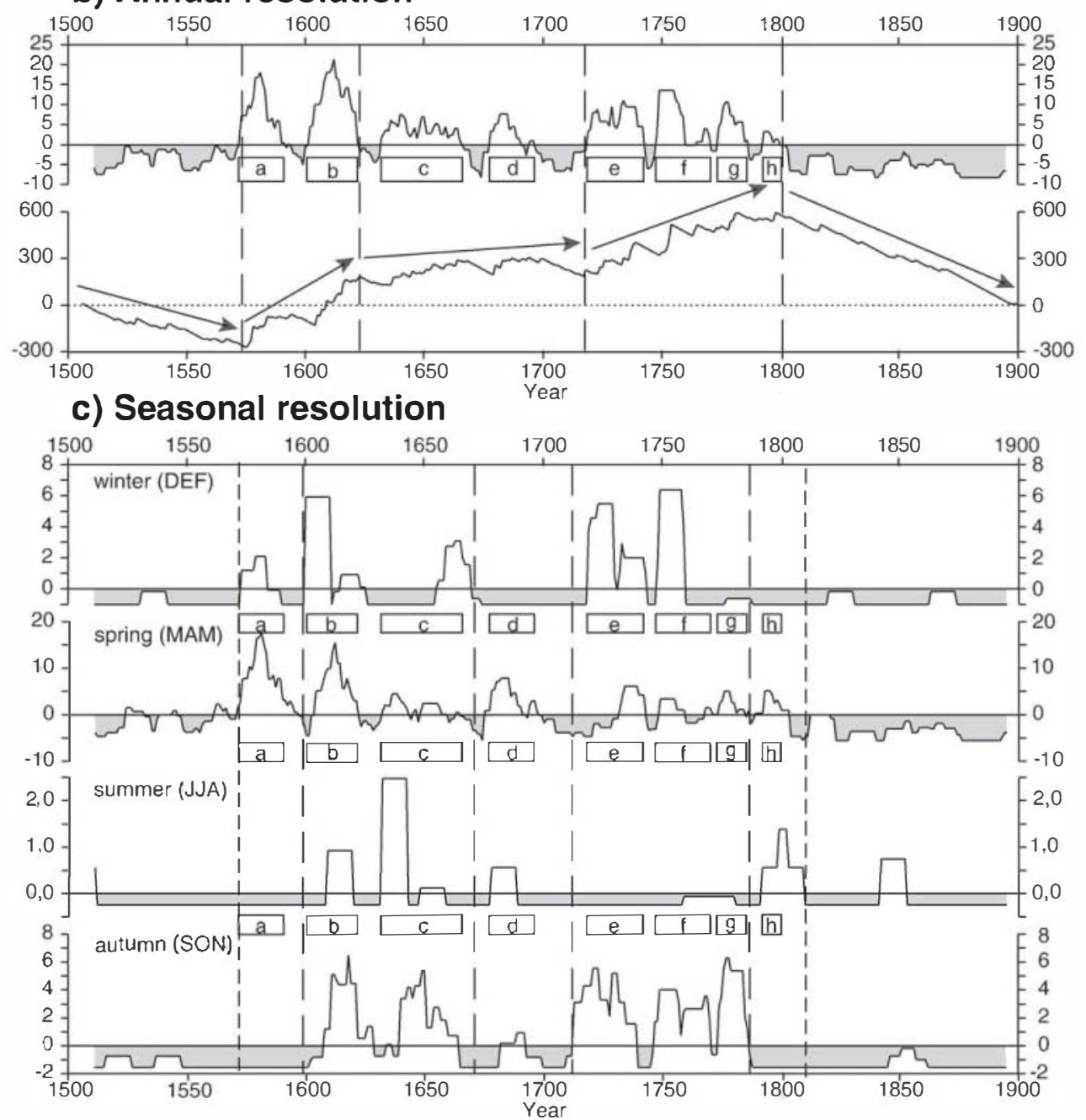

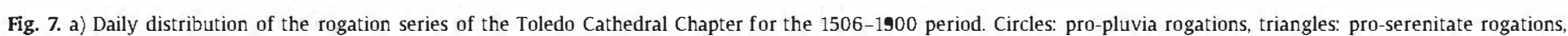

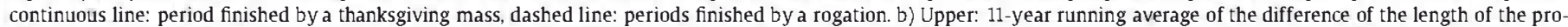

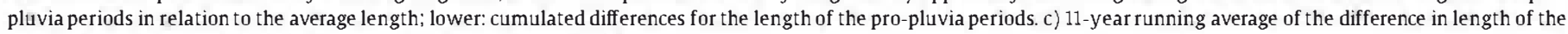
pro-pluvia periods in relation to the average length on a seasonal basis. 
Despite the good correlation between the DRI and the PP $(0.74$, $p=0.014)$, the Pearson's correlation coefficient between PP and the DL is higher and statistically more meaningful ( $r=0.96$, $p<0.001$ ) than the correlation between the DRI and the DL $(r=0.58, p=0.076)$. In addition, Fig. 5a shows the good agreement in location and trends of the PP against the DL, whilst while the DRI fails to characterize some drought events as the resolution of the DRI (discrete scale) is coarser than the PP resolution (continuous scale).

The comparison of the Drought Rogation Index and the pro-pluvia period method applied on an annual scale (the DRI basis) reveals differences in the estimation of the severity of the droughts (Fig. 6a). The most evident case is the evaluation of the 16th century, with a high number of Level III rogations, and the lack of coincidence in the absolute and relative maxima (only five on twelve are coincidental in both methods).

However, the 31-year running average (following Martin-Vide and Barriendos, 1995; Barriendos, 1997) on the standardized indexes shown in Fig. $6 \mathrm{~b}$ reveals that trends in both series are very similar besides the shift of the first maxima which is placed in the late 16th century by the DRI (dashed line) and at the first half of the 17th century by the PP method (thick line). This shift is related to the anomalous number of Level III rogations during the 16th century (Fig. 2b), what has been related in Section 3.2 to social factors during this period.

It is worth to mention that the same procedure applied on the nonweighted sum of the annual rogations (dotted line) is also coincidental with the results of both methods. This implies that the longer term trends, not masked by the 31-year running average, are less sensitive to the manipulation of data.

\section{Results and discussion}

4.1. Drought characterization by the pro-pluvia period method for Toledo for the 1506-1900 period

The rogation series of the Toledo Cathedral Chapter for the 15061900 period, applying the pro-pluvia period (PP) method, is composed by: 85 PP finished by thanksgiving masses, 25 PP not finished by thanksgiving masses, 50 single PP, 9 pro-serenitate periods finished by a thanksgiving mass, 4 pro-serenitate periods without a final thanksgiving mass and 8 single pro-serenitate rogations (Fig. 7a).

Taking into account that most of the record is composed by missing values, to analyze this series these values have been replaced by 0 and an 11-year moving average filter has been applied as the best option between the non-filtered series, too noisy, and the 31-year filter (the "climatological normals" period), which overweighs the 0 values causing shifts in the relative minima and maxima. Filtering on an annual scale of the PP reveals three main phases on the basis of their length (Fig. 7b upper):

1) 1506-1575: Droughts are scarce and their lengths are under the average during the whole phase.

2) 1576-1800: The more severe droughts develop during this phase. Values are upon the average, but short periods below average ( 3 to $22 \mathrm{yr}$ in length each) appear with a frequency around $33 \mathrm{yr}$. This phase shows an early (1576-1624) and a late (1719-1800) stages of severe droughts detached by a middle stage (1625-1718) of less severe droughts (Fig. 7b lower).

3) 1800-1900: Scarce droughts that show the minimum values of the series and are all below the average.

Table 3

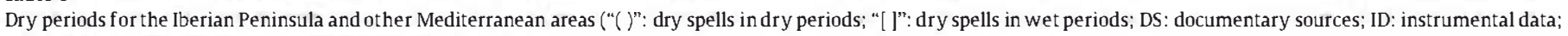
TR: tree-rings, M: models; i.g.: inferred from their graphs)

\begin{tabular}{|c|c|c|c|}
\hline Area & Authors & Dry periods & Comments \\
\hline Toledo (central Spain) & This work & $1576-1600,1601-1675,1711-1775,1775-1810$ & DS, ID \\
\hline Haro (N Spain) & Saz and Creus (2001) & $\begin{array}{l}1590-1605,1646-1655,1751-1759,1768-1772,1870-1882 \text {, beginning } \\
\text { of the } 20 \text { th } \mathrm{c} ., 1963-1974\end{array}$ & TR \\
\hline Zaragoza (NE Spain) & Creus et al. (1997) & $1560-1600,1630-1640,1670-1700,1710-1715,1730-1800$ & TR, i.g. \\
\hline Zaragoza (NE Spain) & Vicente-Serrano and Cuadrat (2007) & $\begin{array}{l}\text { ca. } 1635,1725-1755,1765-1800, \text { ca. } 1825,1870 \text { s, } 1900 \text { s, } 1920 \text { s, } \\
1940 \text { s, } 1960 \text { s, } 1980 \text { s, } 1990 \text { s }\end{array}$ & DS, ID \\
\hline Cataluña (NE Spain) & Barriendos (1997), Barriendos et al. (1998) & $1521-1560,2$ nd half 18 th $\mathrm{c}$ & DS, i.g. \\
\hline Andalucía (S Spain) & Rodrigo et al. (1999, 2000) & $1501-1589,1650-1775,1938-1997$ & DS \\
\hline Spain & Rodrigo and Barriendos (this volume) & $\begin{array}{l}\text { Spring: } \\
\text { Barcelona (NE Spain): } \\
\text { 16th c., 2nd half } 17 \text { th-1st half } 18 \text { th, } 1 \text { st half } 20 \text { th. } \\
\text { Murcia (SE Spain): } \\
\text { 1675-1725, } 1775-1825,1840-1875,1900-1940 \\
\text { Sevilla (S Spain): } \\
1560 \text { s, } 1670 \text { s, } 1750 \text { s, ca. } 1815-1860,1990 \text { s, late } 20 \text { th c. } \\
\text { Annual: } \\
\text { Bilbao (N Spain): } \\
1640 \text { s, ca. } 1660-1740,1780-1830,1890 \text { s, late } 20 \text { th c. } \\
\text { Zamor (NW Spain): } \\
\text { Ca. } 1625-1645,1660-1700,1700-1725,1725-1800,1 \text { st half } 20 \text { th c., } \\
\text { 1970-2000 } \\
\text { Toledo (central Spain): } \\
\text { 1555-1570, } 1600-1615,1720-1760,1780-1800,1820 \text { s, 1920s, 1950s, } \\
\text { late 20th c. }\end{array}$ & DS \\
\hline Spain & Martín-Vide and Barriendos (1997) & $1566-1567$, last third of 18 th $\mathrm{c}$. & DS \\
\hline Spain & Manrique and Fernández-Cancio $(1999,2000)$ & $1664-1693,1874-1903,1904-1933$ & TR \\
\hline N Morocco & Till and Guiot (1990) & $\begin{array}{l}1499-1542,1575-1596,1607-1663,1680-1694,1714-1759,1779-1798, \\
1805-1835,1858-1887\end{array}$ & TR \\
\hline S Italy & Diodato, N. (2007) & $\begin{array}{l}{[1680-1695], 1710-1797(1710-1740,1755-1797),[1820-1840,1850-1875],} \\
1920-2002(1920-1955,1990-2002)\end{array}$ & DS, i.g. \\
\hline N France & Masson-Delmotte et al. (2005) & $1650-1700,1760-1780,1800$ s, $1880-1925,1950$ s, $1990-2000$ & TR (isotopes), i.g. \\
\hline Mediterranean & Guiot et al. (2005). Brewer et al. (2007) & $\begin{array}{l}1500-1665(1500-1520,1535-1560,1590-1605,1615-1640,1645-1665), \\
{[1765-1780,1850-1870,1920-1935,1940-1960], 1980-2000}\end{array}$ & TR, M, i.g. \\
\hline
\end{tabular}


Concerning the 1576-1800 period, seasonal analysis improves its characterization allowing the identification of several stages during this phase (Fig. 7b, c).

Visual inspection of the record of the 1576-1624 period shows two very similar peaks at annual level (Fig. 7b) but the seasonal decomposition reveals that the "a" peak is supported by severe spring droughts whilst while the "b" peak is composed by droughts in all the seasons (Fig. 7c). Considering that spring rogations are easier to trigger than during the other seasons, it is evident that the "b" peak means a drier period than the "a" peak.

Something similar happens for the 1625-1718 period. On an annual scale " $c$ " and " $d$ " peaks are very similar, but on a seasonal scale the " $c$ " peak collects rogations in all the seasons (including the highest values for summer, a season with low weight in farming) while the " $d$ " peak is mostly supported by spring rogations.

For the 1719-1800 period four annual peaks are identified. The "e" and "f" peaks are very similar on a seasonal scale as both are supported by autumn and winter rogations while spring rogations are secondary. The " $g$ " and " $h$ " peaks are relatively different as in both cases the winter pro-pluvia period are short but while in the " $g$ " peak the autumn period is meaningful, the " $h$ " peak is mostly supported by the summer rogations.

This characterization allows to precise the boundaries derived from the annual analysis:

1) 1506-1575: few droughts (values below the average) distributed along most of the year except for summer.

2) 1576-1600: main pro-pluvia periods correspond to spring.

3) 1601-1775: it is the driest period. There were more or less continued rogations for all the seasons. It is composed by three stages:

a) 1600-1675 (earlystage): it presents the most ex reme values of the whole series. Pro-pluvia periods appear frequently in all the seasons.

b) $1676-1710$ (middle stage): it roughly coincides with the Maunder Minimum (1675-1715). It is characterized by climatic bonanza that it is only broken by some spring and few summer pro-pluvia periods. c) 1711-1775 (late stage): droughts are present in all the seasons except for summer.

4) 1775-1810: few droughts are recorded during this period but for some summer and few spring rogations.

5) 1810-1900: there are almost no meaningful pro-pluvia periods but for a short subdued episode around 1850-60 when short pro-pluvia periods appear in summer and autumn.

\subsection{Comparison with other areas in Spain and around the Mediterranean region}

Other records around Spain and the Mediterranean area are presented in Table 3.

For Spain, the series located in the interior (Toledo, Haro, Zaragoza, Zamora) show overlapping dry periods but with different duration and initial dates.

Differences increase when we consider the coastal and southern locations (Bilbao, Cataluña, Murcia, Sevilla). In this case, dry periods can be simultaneous to wet periods in other places (as the case of Barcelona and Sevilla, Rodrigo and Barriendos, this volume).

It is remarkable that the case of the 16th century as for interior locations the dry period is restricted to the last third of the century but for the coastal and southern areas it was dry almost the whole century.

The same situation happens during the change between the 17 th and 18th centuries. In this period, Toledo, Haro and Zaragoza show an increase in rainfall whereas the dry conditions were continuous in the transition from one century to the other in Andalucía, Barcelona, Murcia, Bilbao and Zamora.

For the 19th century differences are notable among Sevilla and Murcia and the rest of locations as, for these cities, this century shows dry conditions for the first two thirds of the century while these conditions arrive to the other locations towards the end of the century.

That spatial variability has been also found in studies about the 20th century droughts. Santos et al. (2000) divided the Iberian Peninsula in Atlantic Iberia, Central Iberia and Western Mediterranean domains. Olcina (2001) differentiated four climatological settings related to

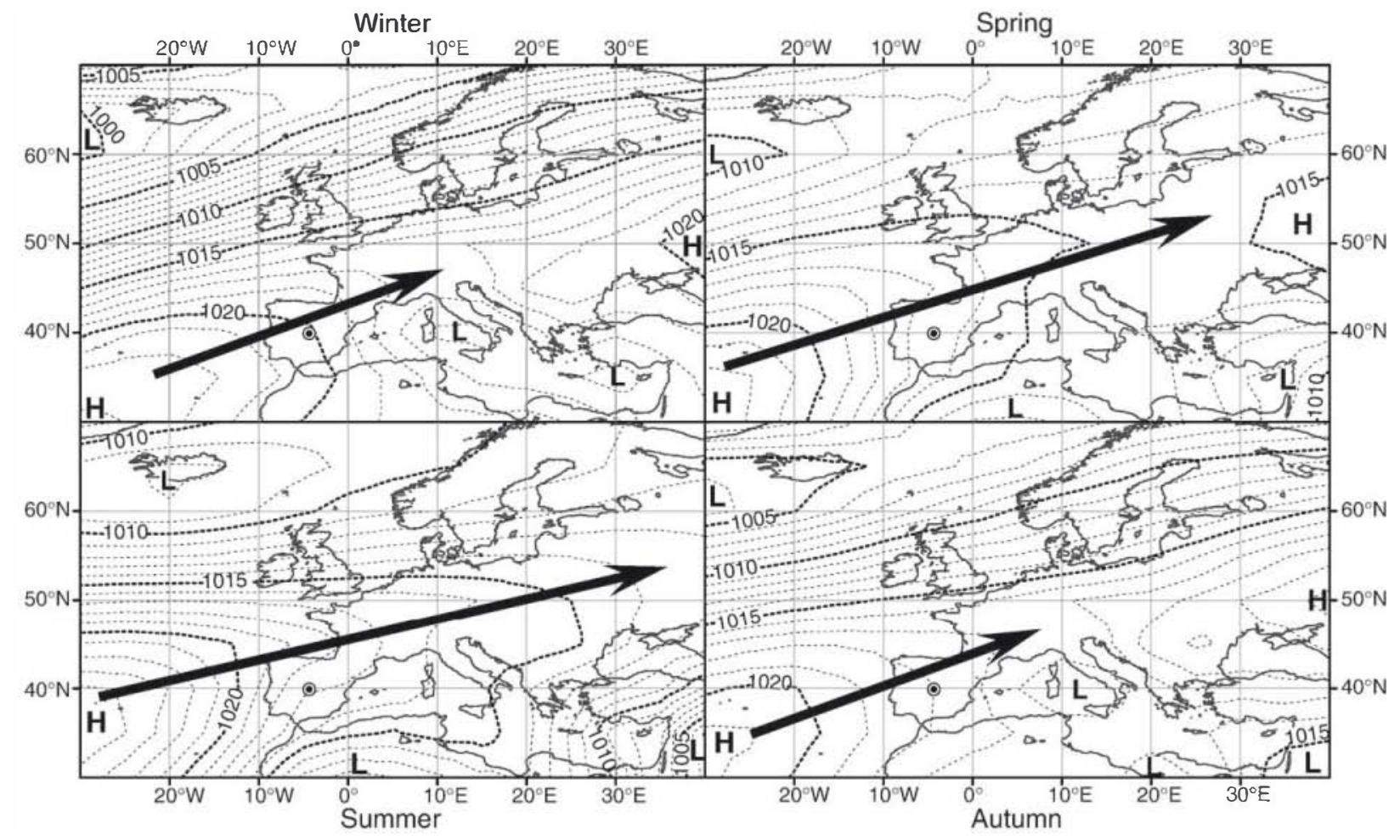

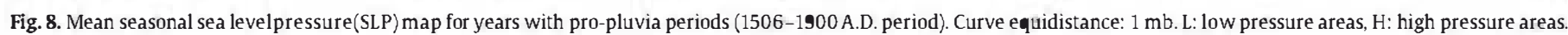


drought: the Atlantic domain, the Mediterranean, mixed AtlanticMediterranean and an inland domain. Cuadrats and Vicente-Serrano (2004) found differences among the North, North-East, South-East and Central-Western regions. Lana et al. (2006) found a N-S gradient in the length of the dry spells with some deviations in the vicinity of the Mediterranean Sea and the Atlantic Ocean. Vicente-Serrano (2006) realized that for short drought time scales ( 1 to 3 months) the Iberian Peninsula can be split in homogeneous classes, but as the time scale increases ( 12 to 36 months) the spatial complexity increases too, being impossible to define homogeneous regions.

When comparing to other points around the western Mediterranean, these show patterns similar to those of the coastal and southern areas of Spain, except for the N Morocco series (Till and Guiot, 1990) and the drought reconstruction for the Mediterranean region of Guiot et al. (2005) and Brewer et al. (2007) that seem to be a mixture of both inland and coastal Spain.

\subsection{Atmospheric situations in relation to drought events}

Rainfall in central Spain has been related to transient low pressure systems with Atlantic origin (Zorita et al., 1992; Trigo et al., 2004a) while dry conditions, or lower than average precipitation, have been ascribed to large-scale anticyclonic circulation types (Trigo and DaCamara, 2000; Goodess and Jones, 2002). The topographical closure of this area to the east and the smoother topography to the west (Fig. 1) imply a greater influence of the cyclogenesis of Atlantic origin than of Mediterranean origin.

Esteban-Parra et al. (1998) analyzed the precipitation anomalies in Spain for the 1880-1992 period and identified a main EOF (Empirical Orthogonal Function) centred in Andalusia and the interior of Spain, relating low precipitation to high values of Azores central pressure or an eastward shift of its mean position and positive values of the NAO index and strong westerlies. They point that westerlies are not associated with rain in the Iberian Peninsula as they need an intensification of the high pressure in westem Iberia, producing blocking situations over it. The influence of the Atlantic cyclogenesis is reaffirmed by Marshall et al. (2001) and Paredes et al. (2006) who indicate that the preferred location of the Atlantic storm-track paths is controlled by the NAO pattern.

The relation of rainfall in Spain to the NAO pattem has been showed by several researchers (Trigo and DaCamara, 2000; Rodrigo et al., 2000; Goodess and Jones, 2002; Trigo et al., 2004b) and Trigo et al (2004a) attributed dry winter conditions to a northern extension of the Azores high.

However, precipitation changes have been also linked to the ENSO (Rodó et al., 1997; Morala et al., 2003; Knippertz et al., 2003), to the Eastern Atlantic and Western Russia patterns (Rodríguez-Puebla et al., 2001), to other patterns (Pauling et al., 2006), or to a blocking Atlantic mechanism and the East Atlantic Jet as more representative than the NAO (Martin et al., 2004), covering a wide spatial range of patterns.

Looking to the atmospheric situations in relation to drought events, maps of sea level pressure (SIP), using the data of Luterbacher et al. $(2002 a)$, were elaborated for the documentary period averaging the SIP by season over years with rogations (Fig. 8).

\section{Table 4}

Seasonal correlation of the pro-pluvia period against NAOi reconstructions of Luterbacher et al. (2002b) and Cook et al. (2002) for 1506-1900 A.D.

\begin{tabular}{llllllr}
\hline & \multicolumn{5}{c}{ Pro-pluvia period } \\
\cline { 3 - 7 } \cline { 3 - 6 } NAO Index & Luterbacher et al. & Winter & -0.0480 & $0.1875^{*}$ & -0.4293 & 0.0492 \\
& (2002b) & Spring & & 0.1204 & -0.3795 & 0.1210 \\
& & Summer & & & -0.2240 & -0.2716 \\
& & Autumn & & & & 0.0078 \\
& Cook et al. (2002) & DJFM & -0.1903 & $0.2461^{* *}$ & 0.1785 & 0.1768 \\
\hline
\end{tabular}

*: $p<0.1 ; * *: p<0.01$ (other cases: $p>0.1$ ).

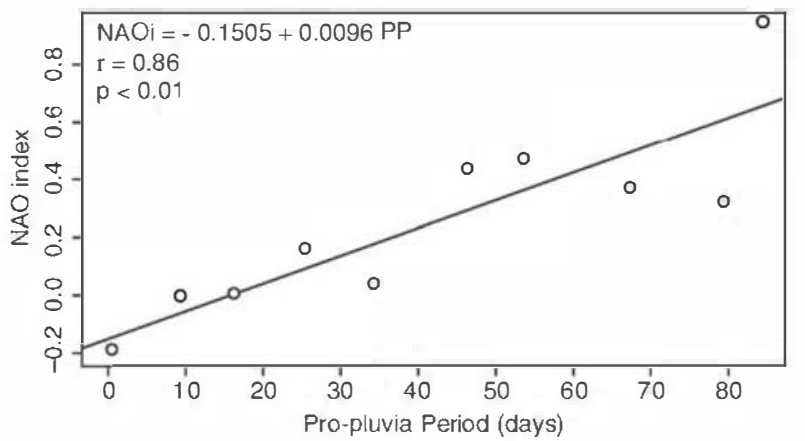

Fig. 9. Lineal regression of the spring and autumn pro-pluvia periods indexes for Toledo (values grouped in 10-dayintervals) for the period 1506 to 1900 against the reconstruction of the NAO index (Cook et aL, 2002).

These maps show that from the 16th to 19th centuries the most common synoptic pattern for droughts on all the seasons corresponds to ridges of marine tropical air masses entering from the Atlantic to Europe. The $1015 \mathrm{mb}$ isobar is always located around the south of England and the "Icelandic" lower pressures move from $55^{\circ} \mathrm{N}$ to $60^{\circ} \mathrm{N}$. However, there are differences among seasons. Spring and summer are characterized by Iceland-Azores pressure gradients varying from $10 \mathrm{mb}$ (spring) to $16 \mathrm{mb}$ (summer) and Azores-Lisbon gradients ranging from $4.5 \mathrm{mb}$ (spring) to $6.5 \mathrm{mb}$ (summer), and two centres of lower pressures located in North Africa and the Near East. For winter and autumn the Iceland-Azores pressure gradient fluctuates from $19.5 \mathrm{mb}$ (winter) to $15.5 \mathrm{mb}$ (autumn), the Azores-Lisbon gradient is $1-1.5 \mathrm{mb}$ (winter) to $2 \mathrm{mb}$ (autumn), and the lower pressures locate in a shallow trough extending from Cyprus to the Tyrrhenian Sea, cutting the Atlantic Ridge that nearly only affects the Iberian Peninsula.

Seasonal (Fig. 8) and monthly reconstruction of SLP show that, during drought periods, the Azores high remained stable at a location around $30^{\circ}-35^{\circ} \mathrm{N}$ and $25^{\circ}-30^{\circ} \mathrm{W}$, similar to the situations described by Esteban-Parra et al. (1998) and Trigo et al. (2004a), causing a displacement of the storm fronts to a northern position. The synoptic patterns showed in Fig. 8 are comparable to the positive phase of the North Atlantic Oscillation (NAO) (Hurrell, 1995).

Comparison for the non non-instrumental period (1506-1900 A.D.) of the pro-pluvia period index and the reconstructions of the NAO index of Luterbacher et al. (2002b) and Cook et al. (2002) provides a weak correlation (Table 4) although it reflects the connection between the winter or DJFM NAO index and the spring rainfall. This relation improves if we group the pro-pluvia period values in intervals. Fig. 9 shows the relation between the spring and autumn pro-pluvia period values grouped by intervals of 10 days, and an additional interval for the 0 value, and the DJFM reconstruction of the NAO index of Cook et al. (2002).

These relations demonstrate that the North Atlantic Oscillation is one of the mechanisms that influence drought development in central Spain since 1506.

This result is compatible with the more wide scale schemes as those of Zorita et al. (1992), González-Rouco et al. (2000) or Xoplaki et al. (2004) who, for a regional analysis, still recognize the weight of local factors, weight that increases as we reduce the spatial scale.

\section{Conclusions}

Rogations are a valuable method to estimate droughts in historical climatology. Commonly used annual weighted sums bias the results towards the spring rogations which are triggered by less severe droughts than in other seasons due to their relation to farming activity.

31-year running average of processed data allows to identify longer rends despite the method used for the analysis of rogations (simple sum, weighted sums, length of rogation periods). But it filters higher frequency signals which are lost. 
The proposed pro-pluvia periods method offers some advantages in comparison to the previous methods used in rogation analyses:

1. Distribution of rogation weights is continuous instead of discrete (as using levels attributed on basis to liturgical acts). This reduces the influence of local/regional factors and cultural or social uses and it provides a more objective scale.

2. The relation between the pro-pluvia period and the drought length allows to obtain an approximation of the length of the drought events on an intraannual basis.

3. Annual to longer time scales analysis of these data can be characterized more precisely by using seasonal data.

Implementation of this method on the rogation series of the Toledo Cathedral Chapter allows to describe thoroughly the drought evolution for this period and to characterize the 1506-1900 period in this region:

4. There is an increase in the number of droughts for all the seasons and their length for the 1601-1775 A.D. period. The accumulation of autumn rogations for this period is especially meaningful.

5. For the 1676-1710 A.D. period, there is an evident shortening of the length of droughts that are mostly placed in spring. This "normality" in rainfall has been also described by Alcoforado et al. (2000) for southern Portugal and by Barriendos (1997) for the Iberian Peninsula from rogation data.

Despite the results and temporal resolution, it must be stressed that the use of pro-pluvia rogations gives only information about drought periods and not about rainfall in general. Consequently, comparison with other records must be carried out carefully. Moreover, the 17 th to 18 th centuries period is characterized by periods when floods and droughts alternate quickly and the reconstruction provided here is just the record of a part of such phenomena.

However, we believe that the methodology or working philosophy applied in this paper can be extended successfully to other kinds of historical data. Droughts, heat or cold waves, stormy periods, or any other "long term" phenomena providing a documentary series can be quantified by the period methodology. This can reduce the uncertainty inherent to the individual perception of the phenomena or its overestimation by an accumulation of news about it in a short period.

Despite the presence of commonalities among different locations in Spain and the Western Mediterranean area, there are meaningful differences on the timing and length of drought periods. Variability of the distribution of droughts in time and space stresses the need to increase the number of records and their lengths in order to improve the regional reconstruction of this phenomenon. Uncertainties about the weight of local and regional patterns must be explored with the help of new reconstructions.

Such spatial heterogeneity is also evidenced by the feeble correlation to the atmospheric patterns, but a certain relation to the NAO can be invoked and this is supported by the dominance of the influence of the Azores pressure high on such events.

\section{Acknowledgements}

This research is supported by the Spanish Ministry of Science and Education (MEC) projects REN2002-04433-CO2 and CGI2005-06458CO2-01/HID, and the Millennium project IP 017008-2 EU. Fernando Dominguez-Castro work is supported by a MEC research grant (BES2003-0482) and Mariano Barriendos work is supported by MEC Research Programme "Ramón y Cajal". The Spanish Meteorological National Institute (INM) has provided the instrumental data of Madrid and Toledo. The authors are very grateful to Elena Xoplaki and an anonymous reviewer for helping us to improve the manuscript with their useful comments. We extend our sincere thanks to Serge Planton co-editor of this issue for his job and advice concerning the English language.

\section{References}

Akkemik, Ü., 2000. Dendroclimatology of umbrella pine (Pinus pine L.) in Istanbul, Turkey. Tree-Ring Bulletin 56, 17-20.

Akkemik, Ü., Aras, A., 2005. Recostruction (1689-1994 AD) of April-August precipitation in the southern part of central Turkey. International Journal of Climatology 25 , $537-548$.

Akkemik, Ü., Dagdeviren, N., Aras, A., 2005. A preliminary reconstruction (A:D: 16352000 ) of spring precipitation using oak tree-rings in the western Black Sea region of Turkey. International Journal of Biometeorology 49, 297-302.

Akkemik, Ü., D'Arrigo, R., Cherubini, P., Kose, N., Jacoby, G.C., 2007. Tree-ring reconstructions of precipitation and streamflow for north-western Turkey International Journal of Climatology. doi: 10.1002/joc.1522.

Alcoforado, M.J., Nunes, M.F., Garcia, J.C., Taborda, J.P., 2000. Temperature and precipitation reconstruction in southern Portugal during the late Maunder Minimum (1675-1715). The Holocene 10, 333-340.

Álvarez Vázquez,J.A., 1986. Drought and rainy periods in the province of Zamora in the 17th, 18th, and 19th centuries. In: Iópez Vera, F. (Ed.), Quaternary Climate in Western Mediterranean. Universidad Autónoma de Madrid, Madrid, pp. 221-233.

Alley, W.M., 1984. The Palmer drought severity index: limitations and assumptions Journal of Climate and Applied Meteorology 23, 1100-1109.

Barriendos, M., 1997. Climatic variations in the Iberian peninsula during the late Maunder minimum (AD 1675-1715): an analysis of data from rogation ceremonies. The Holocene 7, 105-111.

Barriendos, M.,2005. Climate and culture in Spain, religious responses to extreme climatic events in the Hispanic Kingdoms (16th-19th centuries). In: Behringer, W., Lehmann, H., Pfister, C. (Eds.), Cultural Consequences of the Little Ice Age. Vandenhoek \& Ruprecht, Göttingen, pp.31-86.

Barriendos, M., Peña,J.C., Martín-Vide, F.J., 1998. Lacalibración instrumental de registros climáticos documentales: aproximación metodológica a resolución anual para el caso de la precipitación en Barcelona (1521-1989). Investigaciones Geográficas 20 , 99-118

Brázdil, R., Pfister, C., Heinz, W., Storch, H.V., Luterbacher, J., 2005. Historical climatology in Europe-the state of the art Climatic Change 70, 363-430.

Brewer, S., Alleaume, S., Guiot, J., Nicault, A., 2007. Historical droughts in Mediterranean regions during the last 500 years: a data/model approach. Climate of the Past 3 , 355-366.

Brunetti, M., Buffoni, L., Mangianti, F., Maugeri, M., Nanni, T., 2004. Temperature, precipitation and extreme events during the last century in Italy. Global and Planetary Change 40, 141-149.

Büntgen, U., Frank, D.C., Nievergelt, D., Esper, J., 2006. Alpine summer temperature variations, AD 755-2004. Journal of Climate 19, 5606-5623.

Byun, H.R., Wilhite, D.A., 1999. Ob jective quantification of drought severity and duration. Journal of Climate 12, 2747-2756.

Casty, C., Wanner, H., Luterbacher, J., Esper, J., Böhm, R., 2005. Temperature and precipitation variability in the European Alps since 1500 . International Journal of Climatolology 25, 1855-1880.

Chbouki, N., Stockton, C.W., Myers, D., 1995. Spatio-temporal patterns of drought in Morocco. International Journal of Climatology 15, 187-205.

Cook, E.R., D'Arrigo, R.D., Mann, M.E., 2002. A well-verified, multiproxy reconstruction of the Winter North Atlantic Oscillation Index since A.D. 1400. Journal of Climate 15 , $1754-1764$

Creus, J., Fernández-Cancio, A., Beorlegui, M., 1995. Reconstrucciones climáticas en Galicia durante las últimas centurias: estudio dendrocronológico. Xunta de Galicia, Santiago de Compostela, Spain.

Creus, J., Fernández-Cancio, A., Manrique, E., 1997. Dendrocronologíay clima del último milenio en España. Aspectos metodológicos y avance de resultados. In: Ibáñez, J.J., Valero-Garcés, B.L., Machado, C. (Eds.), El paisaje mediterráneo a través del espacio yel tiempo. Implicaciones en la desertificación, pp. 311-330. Geoforma Ediciones, Logroño, Spain

Cuadrats, J.M., Vicente-Serrano, S.M., 2004. Comportamiento de las sequías en la Península Ibérica. Análisis mediante el Standardized Precipitation Index. In: García Codrón, J.C. Diego Liaño, C. Fermández de Arróyabe Hernáez, P., Garmendia Pedraja, C., Rasilla Álvarez, D. (Eds.), El Clima entre el Mar y la Montaña. Asociación Española de Climatología y Universidad de Cantabria, Geoforma Ediciones, Santander, pp. 245-254. $n^{\circ} 4$

Cullen, H.M., deMenocal, P.B., Hemming, S., Hemming, G., Brown, F.H., Guilderson, T. Sirocko, F., 2000. Climate change and the collapse of the Akkadian empire: evidence from the deep sea. Geology 28, 379-382.

deMenocal, P., 2001. Cultural responses to climate change during the Late Holocene. Science 292, 667-673.

D`Arrigo, R.D., Cullen, H.M., 2001. A 350-year(AD 1628-1980) reconstruction of Turkish precipitation. Dendrochronologia 19, 167-177.

Diodato, N., 2007. Climatic fluctuations in southern Italy since the 17th century: reoonstruction with precipitation records at Benevento. Climatic Change 80, 411-431.

Domínguez-Castro, F., 2004. Evolución climática de la meseta sur de la Península Ibérica a través del estudio de las rogativas realizadas en el cabildo de Toledo entre 1506 y 1850. Trabajo para la obtención del Diploma de Estudios Avanzados. Universidad Autónoma de Madrid, Spain.

Drysdale, R., Zanchetta, G., Hellstrom, J., Maas, R., Fallick, A., Pickett, M., Cartwright, I., Piccini, L., 2006. Late Holocene drought responsible for the collapse of Old World civilizations is recorded in an Italian cave flowstone. Geology 34, 101-104. 
Esper, J., Frank, D., Büntgen, U., Verstege, A., Luterbacher, J., Xoplaki, E., 2007. Iong-term drought severity variations in Morocco. Geophysisical Research Letters 34, L17702. doi: $10.1029 / 2007$ GL030844

Esteban-Parra, M.J., Rodrigo, F.S., Castro-Díez, Y., 1998. Spatial and temporal patterns of precipitation in Spain for the period 1880-1992. Intemational Joumal of Climatology $18,1557-1574$

Frank, D., Esper, J., 2005. Temperature reconstructions and comparisons with instrumental data from a tree-ring network for the European Alps. International Journal of Climatology 25, 1437-1454

Gibbs, W.J., Maher, J.V., 1967. Rainfall Deciles as Drought Indicators. Bureau of Meteorology Bulletin 48. Commonwealth of Australia, Melbourne.

Giralt, E., 1958. En torno al precio del trigo en Barcelona durante el siglo XVI. Hispania $18,38-61$.

Glueck, M.F., Stockton, C.W., 2001. Reconstruction of the North Atlantic Oscillation, 1429-1983. International Journal of Climatolology 21, 1453-1465.

González-Rouco,J.F., Heyen, H.,Zorita, E., Valero, F., 2000. Agreement between observed rainfall trends and climate change simulations in Southern Europe. Journal of Climate 13, 3057-3065

Goodess, C. Jones, P.D., 2002. Links between circulation and changes in the characteristics of Iberian rainfall. Intemational Journal of Climatology 22, 1593-1615

Guiot,J., Alleaume, S., Nicault, A., Brewer, S., 2005. The Mediterranean droughts during the last 650 years: reconstruction from tree-rings and climate model simulation. Geophysical Research Abstracts 7, 02471

Haug, G.H., Gunther, D., Peterson, L.C., Sigman, D.M., Hughen, K.A., Aeschlimann, B., 2003. Climate and the collapse of Maya civilization. Science 299, 1731-1735.

Hayes, M.J., Svoboda, M.D., Wilhite, D.A., Vanyarkho, O.V., 1999. Monitoring the 1996 drought using the standardized precipitation index. Bulletin of the American Meteorological Society $80,429-438$.

Hisdal, H., Tallaksen, L.M. (Eds.), 2000. Drought Event Definition. ARIDE Technical Report 6. University of Oslo, Oslo. Norway. 45 pp.

Hodell, D.A., Brenner, M., Curtis, J.H., Guilderson, T., 2001. Solar forcing of drought frequency in the Maya Lowlands. Science 292, 1367-1370.

Hodell, D.A., Brenner, M., Cur tis, J.H., 2007. Climate and cultural history of the Northeastern Yucatan Peninsula, Quintana Roo, Mexico. Climatic Change 83, 215-240.

Hurrell, J.W., 1995. Decadal Trends in the North Atlantic Oscillation: regional temperatures and precipitation. Science 269, 676-679.

Knippertz, P., Ulbrich, U., Marques, F., Corte-Real, J., 2003. Decadal changes in the link between El Niño and springtime North Atlantic Oscillation and European-North African rainfall. International Journal of Climatology 23, 1293-1311.

Lana, X., Martínez, M.D., Burgueño, A., Serra, C., Martín-Vide, J., Gómez, L., 2006 Distribution of long dry spells in the Iberian Peninsula, years 1951-1990 International Journal of Climatology 26, 1999-2021.

Le Roy Iadurie, E., 1983. Histoire du climat depuis I'An MiL Flammarion, Paris

Lloyd-Hughes, B., Saunders, M.A., 2002. A drought climatology for Europe. International Journal of Climatology 22, 1571-1592.

López Salazar, J., Martin Galán, M., 1981. La producción cerealista en el Arzobispado de Toledo 1463-1699. Cuadernos de Historia Moderna y Contemporánea 2, 21-103.

Luterbacher, J., Xoplaki, E., Dietrich, D., Rickli, R., Jacobeit, J., Beck, C., Gyalistras, D. Schmutz, C., Wanner, H., 2002a. Reconstruction of Sea Level Pressure fields over the Eastern North Atlantic and Europe back to 1500. Climate Dynamics 18 $545-561$

Luterbacher, J., Xoplaki, E., Dietrich, D., Jones, P.D., Davies, T.D., Portis, D., GonzálezRouco, J.F., von Storch, H., Gyalistras, D., Casty, C., Wanner, H., 2002b. Extending North Atlantic Oscillation reconstructions back to 1500. Atmospheric Science Letters 2, 114-124.

Luterbacher, J., Dietrich, D., Xoplaki, E., Grosjean, M., Wanner, H., 2004. European seasonal and annual temperature variability, trends, and extremes since 1500. Science 303, 1499-1503.

Luterbacher, J., Xoplaki, E., Casty, C., Wanner, H., Pauling, A., Küittel, M., Rutishauser, T. Brönnimann, S., Fischer, E., Fleitmann, D., González-Rouco, F.., García-Herrera, R. Barriendos, M., Rodrigo, F., Gonzalez-Hidalgo, J.C., Saz, M.A., Gimeno, L., Ribera, P. Brunet, M., Paeth, H., Rimbu, N., Felis, T., Jacobeit, J., Dünke-loh, A., Zorita, E., Guiot, J., Türkes, M., Alcoforado, M.J., Trigo, R., Wheeler, D., Tett, S., Mann, M.E., Touchan, R. Shindell, D.T., Silenzi, S., Montagna, P., Camuffo, D., Mariotti, A., Nanni, T., Brunetti, M., Maugeri, M., Zerefos, C., DeZolt, S., Lionello, P., Nunes, M.F., Rath, V., Beltrami, H. Garnier, E., Le Roy Iadurie, E., 2006. Mediterranean climate variability over the las centuries: a review. In: Lionello, P., Malanotte-Rizzoli, P., Boscolo, R. (Eds.), The Mediterranean Climate: an Overview of the Main Characteristics and Issues Elsevier, Amsterdam, pp. 27-148. the Netherlands.

Manrique, E., Fernández-Cancio, A., 1999. Evolución fitoclimática de los últimos siglos en España a partir de reconstrucciones dendroclimáticas. Investigación Agraria: Sistemas y Recursos Forestales (Fuera de Serie 1) 75-91.

Manrique, E., Fernández-Cancio, A., 2000. Extreme climatic events in dendroclimatic reconstructions from Spain. Climatic Change 44, 123-138.

Martín, M.L., Luna, M.Y., Morata, A., Valero, F., 2004. North Atlantic teleconnection patterns of low-frequency variability and their links with springtime precipitation in the western Mediterranean. International Journal of Climatology 24 213-230.

Martín-Vide, J., Barriendos, M., 1995. The use of rogation ceremony records in climatic reconstruction: a case study from Catalonia (Spain). Climatic Change 30 201-221

Martín-Vide, J., Barriendos, M., 1997. Paleometeorología: aportaciones al conocimiento de los cambios pluviométricos durante el último medio milenio en la Península Ibérica. In: Ibáñez, J.J., Valero-Garcés, B.L., Machado, C. (Eds.), El paisaje mediterráneo a través del espacio y el tiempo. Implicaciones en la desertificación, pp. 331-342. Geoforma Ediciones, Iogroño, Spain. M., Saravanan, R., Visbeck, M., 2001. North Atlantic climate variability: phenomena, impacts and mechanisms. International Journal of Climatology 21, 1863-1898.

Martinelli, N., 2004. Climate from dendrochronology: latest developments and results. Global and Planetary Change $40,129-139$.

Masson-Delmotte, V., Raffalli-Delerce, G., Danis, P.A., Yiou, P., Stievenard, M., Guibal, F Mestre, O., Bernard, V., Goosse, H., Hoffmann, G., Jouzel, J., 2005. Changes in European precipitation seasonality and in drought frequencies revealed by a fourcentury-long tree-ring isotopic record from Brittany, western France. Climate Dynamics 24, 57-69.

McKee, T.B., Doesken, N.J., Kleist, J., 1993. The relationship of drought frequency and duration to time scales. Preprints of the 8 th Conference on applied Climatology, pp. 179-184. Anaheim, California.

Morala, L., Serrano, A., García,J.A., 2003. Detecting quasi-oscillations in the monthly precipitation regimes of the Iberian Peninsula. Annales Geophysicae 21, 819-832.

Munaut, A.V., 1982. The Mediterranean area In: Hughes, M.K., Kelly, P.M., Pilcher, J.M., IaMarche, V.C. (Eds.), Climate from Tree Rings. Cambridge University Press, Cambridge, pp. 151-155.

Nicoll, K., 2004. Recent environmental change and prehistoric human activity in Egypt and Northern Sudan. Quaternary Science Reviews 23, 561-580.

Olcina, C., 2001. Tipología de las sequias en España. Ería 56, 201-227.

Palmer, W.C., 1965. Meteorological Drought. Research Paper No. 45. US Weather Bureau, Washington, D.C., USA.

Paredes, D., Trigo, R.M., García-Herrera, R., Trigo, LF., 2006. Understanding precipitation changes in Iberia in early spring: weather typing and storm-tracking approaches. Journal of Hydrometeorology 7, 101-113.

Pauling, A., Luterbacher, J., Casty, C., Wanner, H., 2006. Five hundred years of gridded high-resolution precipitation reconstructions over Europe and the connection to large-scale circulation. Climate Dynamics 26, 387-405.

Peterson, T.C., Vose, R.S., 1997. An overview of the Global Historical Climatology Network temperature data base. Bulletin of the American Meteorological Society $78,2837-2849$

Piervitali, E., Colacino, M., 2001. Evidence of drought in western Sicily during the period 1565-1915 from liturgical of fices. Climatic Change 49, 225-238.

Raible, C.C., Casty, C., Luterbacher, J., Pauling, A., Esper, J., Frank, D.C., Büntgen, U. Roesch, A.C., Tschuck, P., Wild, M., Vidale, P.L., Schär, C., Wanner, H., 2006. Climate variability - observations, reconstructions, and model simulations for the AtlanticEuropean and Alpine region from 1500-2100 AD. Climatic Change 79, 9-29.

Rodó, X., Baert, E., Comín, F.A., 1997. Variations in seasonal rainfall in Southern Europe during the present century: relationships with the North Atlantic Oscillation and the El Niño-Southern Oscillation. Climate Dynamics 13, 275-284.

Rodrigo, F.S., Barriendos, M., 2008. Reconstruction of seasonal and annual rainfall variability in the Iberian Peninsula (16th-20th centuries) from documentary data. Global and Planetary Change 63, 256-274 (this volume). doi:10.1016/j.gloplacha.2007.09.004.

Rodrigo, F.S., Esteban-Parra, M.J., Pozo-Vázquez, D., Castro-Díez, Y., 1999. A 500-year precipitation record in Southern Spain. Int. J. ClimatoL 19, 1233-1253.

Rodrigo, F.S., Esteban-Parra, M.J., Pozo-Vázquez, D., Castro-Díez, Y., 2000. Rainfall variability in southern Spain on decadal to centennial time scales. International Journal of Climatology 20, 721-732.

Rodríguez-Puebla, C., Encinas, A.H., Sáenz,J., 2001. Winter precipitation over the Iberian peninsula and its relationship to circulation indices. Hydrology and Herat System Sciences 5, 233-244.

Romero, L.E., Máyer, P., 2002. Episodios de sequía en Gran Canaria en el siglo XVII análisis de las rogativas como método de reconstrucción climática. In: Guijarro Pastor, J.A. (Ed.), El clima y el agua. Asociación Española de Climatología, Palma de Mallorca, pp. 533-542.

Santos, M.J., Verissimo, R., Fernandes, S., Orlando, M., Rodrigues, R., 2000. Overview of meteorological drought analysis on Western Europe. ARIDE Technical Report 10 , Water Institute, Lisbon, Portugal. 126 pp.

Saz, M.A. 2004. Temperaturas y precipitaciones en la mitad norte de España desde el siglo XV. Estudio dendroclimático. Consejo de Protección de la Naturaleza. Diputación General de Aragón, Zaragoza.

Saz, M.A., Creus, J., 1999. La variabilidad del clima español en el pasado: frecuencia de valores extremos de temperatura y precipitación reconstruidas desde el $\mathrm{s}$. XV. In: Raso Martín-Vide (Ed.), La climatología española en los albores del siglo XXI Vilassar, Oikos-tau, Asociación Española de Climatología, Serie A No 1, pp. 501-510.

Saz, M.A., Creus, J., 2001. El clima de La Rioja desde el siglo XV. Reconstrucciones dendroclimáticas del observatorio de Haro. Zubía Monográfico 13, 41-64.

Schafer, J.L., 1997. Analysis of Incomplete Multivariate Data. Chapman \& Hall/CRCPress, Boca Raton (Florida)

Tebaldi, C., Hayhoe, K., Arblaster, J.M., Meehl, G.A., 2006. Going to the extremes: an intercomparison of model-simulated historical and future changes in extreme events. Climatic Change 79, 185-211.

Till, C., Guiot, J., 1990. Reconstruction of precipitation in Morocco since 1100 AD based on Cedrus atiantic tree-ring widths. Quaternary Research 33, 337-351.

Touchan, R., Garfio, G.M., Meko, D.M., Funkhouser, G., Erkan, N., Hughes, M.K., Wallin, B.S., 2003. Preliminary reconstructions of spring precipitation in southwestern Turkey from tree-ring width. International Journal of Climatology 23, 157-171.

Touchan, R., Funkhouser, G., Hughes, M.K., Erkan, N., 2005a. Standardized precipitation indices reconstructed from tree-ring widths for the Turkish region. Climatic Change $72,339-350$

Touchan, R., Xoplaki, E., Funkhouser, G., Luterbacher, J., Hughes, M.K., Erkan, N., Akkemik, Ü., Stephan, J., 2005b. Reconstruction of the spring/summer precipitation for the Eastern Mediterranean from tree-rings widths and its connection to largescale atmospheric circulation. Climate Dynamics 25, 75-98. 
Trigo, R.M., DaCamara, C.C., 2000. Circulation weather types and their influence on the precipitation regime in Portugal. International Journal of Climatology 20 , 1559-1581.

Trigo, R.M., Trigo, LF., DaCamara, C.C., Osborn, T.J., 2004a. Climate impact of the European winter blocking episodes from the NCEP/NCAR Reanalyses. Climate Dynamics 23, $17-28$.

Trigo, R.M., Pozo-Vázquez, D., Osborn, T.J., Castro-Díez, Y., Gamíz-Fortis, S., Esteban-Parra, M.J., 2004b. North Atlantic Oscillation influence on precipitation, river flow and water resources in the Iberian Peninsula. International Journal of Climatology 24, 925-944.

Vicente-Serrano, S.M., 2006. Differences in spatial patterns of drought on different time scales: an analysis of the Iberian Peninsula. Water Resources Management 20, 37-60.

Viœente-Serrano, S.M., Cuadrat, J.M., 2007. North Atlantic Oscillation control of droughts in North-East Spain: evaluation since 1600 A.D. Climatic Change 85, 357-379. doi: 10.1007/s 10584-007-9285-9.

Weiss, H., Courty, M.A., Wetterstrom, W., Guichard, F., Senior, L, Meadow, R., Curnow, A., 1993. The genesis and collapse of third millennium North Mesopotamian civilization. Science 261, 995-1004
Wilhite, D.A., Glantz, M.H., 1985. Understanding the drought phenomenon: the role of definitions. Water International 10,111-120.

Xoplaki, E., Maheras, P., Luterbacher, J., 2001. Variability of climate in meridional Balkans during the periods $1675-1715$ and $1780-1830$ and its impact on human life. Climatic Change 48, 581-615.

Xoplaki, E., Gonzalez-Rouco, J.F., Luterbacher, J., Wanner, H., 2004. Wet season Mediterranean precipitation variability: influence of large-scale dynamics and trends. Climate Dynamics 23, 63-78.

Xoplaki, E., Luterbacher, J., Paeth, H., Dietrich, D., Steiner, N., Grosjean, M., Wanner, H., 2005. European spring and autumn temperature variability and change of extremes over the last half millennium. Geophysical Research Letters 32, L15713.

Zamora Pastor, R., 2002. El final de la pequeña edad de hielo. Publicaciones Universidad de Alicante, Alicante.

Zorita, E., Kharin, V., von Storch, H., 1992. The atmospheric circulation and sea surface temperature in the North Atlantic area in winter: their interaction and relevance for Iberian precipitation. Journal of Climate 5, 1097-1108. 